\title{
НЕЙРОПСИХОЛОГІЧНІ ОСОБЛИВОСТІ ОСІБ 3 ДЕВІАНТНОЮ ПОВЕДІНКОЮ
}

Удк: 159.95

\section{Ткач Богдан Миколайович}

Кандидат психологічних наук, докторант лабораторії психологї̈ навчання ім. I. О. Синиці Інституту психології ім. Г.С. Костюка Національної академії педагогічних наук Украӥни, м. Київ (Украӥна)

\begin{abstract}
Анотація. У статті представлено казуальну структуру девіантної поведінки, створену на основі комплексного та системного нейропсихологічного дослідження. Запропоновано нейропсихологічне дослідження здійснювати разом із біометричним (окулографія та ЕЕГ) для усунення елементу суб'єктивності при інтерпретації результатів діагностики. Сформовано три компоненти симптомокомплексу психічної стадії девіацій. Показано, щуо первинний симптомокомплекс представлений мінімальними порушення функціонування передньої частини мозку: орбіто-фронтальної частини префронтальної кори мозку; дорсолатеральної частини префронтальної кори мозку; передньої циингулярної кори мозку; вентромедіальної частини префронтальної кори мозку. Установлено, щчо вторинний симптомокомплекс зумовлений перебуванням особистості під впливом наївного реалізму, домінуванням евристичного мислення $i$ невміння користуватися експертним мисленням у повсякденному жстті; низькою комунікативною компетентністю; дезадаптацією через нездатність вчасно побачити альтернативні иляхи вирішення проблеми. Показано, щүо третинний симптомокомплекс - це, власне, і є адикиія - патологічний гомеостаз. 3 'ясовано, щзо вибір форми адиктивної поведінки не $\epsilon$ стохастичним процесом, а залежить від соціального походження, иіннісно-нормативних стандартів, матеріальних можливостей та інформаційного оточення. Виявлено, щуо при нормальному функціональному стані гіпокампу присутня гедоністична мотивація, а при ослабленому - атарактивна мотивація.
\end{abstract}

Ключові слова: девіантна поведінка, нейропсихологічна діагностика, нейроперсонологія, симптомокомплекс, мозкові дисфункиіï, мотивація, афективна сфера.

Постановка проблеми. Девіантна по- стандартів, була, $є$ i, напевно, буде однією 3 ведінка - поведінка, що відхиляється від найактуальніших проблем в елітарних суспіприйнятих у соціумі ціннісно-нормативних льствах. Оскільки динамізм часу, складність 
соціальної практики та поступ людства постійно змінюють правила та норми у певному соціумі. Глобалізація та інтенсифікація міграції людей загострює проблему конфлікту світоглядів. До того ж цифрова експансія та роботизація кардинально вже міняють буття людства в історичному, культурологічному та аксіологічному контекстах. Крім того, все частіше доводиться мати справу психологам 3 культурною/цивілізаційною патологією. 3 огляду на це проблематика девіантної поведінки вимагає поглибленого нейропсихологічного вивчення.

Аналіз останніх досліджень та публікацій. Якщо на основі досліджень Specker, Carlson, Christenson та Marcotte (1995), Bechara та ін. (2001), Potenza (2001), Cavedini та ін. (2002), Regard, Knoch, Gutling \& Landis (2003), Менделевич (2003), Ткач (2006), Егоров (2006), Андрух (2011) та інших, зробити просту таксономію індивідуальнопсихологічних особливостей, які притаманні особистостям 3 девіантною поведінкою, то це скоріше нагадуватиме опитувальник Т. Лірі «Діагностика міжособистісних відношень», а не «усереднений портрет девіанта» $[1 ; 4 ; 7 ; 9$; $11 ; 12 ; 18-20]$. Зрозуміло, що одна особа не здатна в собі поєднати всі ці властивості, тому створювати «інтегральний профіль девіантної особистості» на основі поєднання непоєднуваного, як це робили попередні дослідники, нема сенсу. Як зазначає Jackson (2015), ні практичної, ні наукової цінності він не матиме че- рез моноказуалістичний принцип його побудови [16].

\section{Виділення невирішених раніше час-} тин загальної проблеми. Через неврахування структури девіантного субстрату/діяльності в сучасному суспільстві та елементів суб'єктивності у процедурі нейропсихологічних досліджень виникає не зовсім коректна інтерпретація сучасних даних нейропсихологічної діагностики. Інтегральний профіль девіантної особистості не дозволяс розробити адекватні підходи до нейропсихологічної корекції.

Метою статті $\epsilon$ вивчення нейропсихологічних особливостей осіб з девіантною поведінкою у сучасному суспільстві для побудови нейропсихологічній концепції девіантної поведінки.

\section{Виклад основного матеріалу і резуль-} татів дослідження. Для дослідження була сформована вибірки, яка складалася з 400 осіб 3 девіантною поведінкою, з рівномірним гендерним розподілом та рівномірним віковим розподілом від 18 до 55 років з типовими для нашого суспільства девіаціями.

Методи дослідження: клінічна бесіда, збір анамнестичних даних та спостереження; вивчення моторної та сенсорної асиметрії завдяки методиці дослідження латеральної організації Е. Д. Хомскої, І. В. Сфімової; загальний медичний огляд. Методологічною основою нашої нейропсихологічної діагностики $€$ теорія системної динамічної локалізації ВПФ Л. С. Виготского та О. Р. Лурії. Центральним 
методом дослідження є синдромальний аналіз порушення ВПФ шляхом діагностики стану нейропсихологічних факторів. Сформована нейропсихологічна батарея у яку входили відібрані методики та проби. Для вивчення стереогнозу, тактильних і соматогностичних функцій було використано такі методики: проба тактильного впізнавання предметів, проби на відмінну тактильну чутливість, локалізація дотику, проба Ферстера, м'язево-суглобове відчуття, вібраційне відчуття, відчуття тиску, відчуття маси. Для вивчення зорового гнозису було використано стимульні матеріали та вебжурнал «National Geographic» для оцінки сприйняття реалістичних зображень, кольоровий гнозис, перекреслених зображень, фігур Поппельрейтера, буквенний та цифровий гнозис, незавершених зображень, химерних зображень, замасковані фігури, цілісність і переключання уваги, проба на коливання зорової уваги, лицевий гнозис (ідентифікація знайомих і незнайомих облич), емоційний гнозис, сюжетні картини, оптико-просторовий гнозис (локалізація об'єктів у просторі, орієнтація в реальному просторі, впізнавання часу на схематичному годиннику, дорожній тест змальовування складних фігур, проба на аналіз просторових відношень, методика ментальних ротації Р. Шепард). Для вивчення слухового гнозису було використано такі методики: сприйняття побутових і природніх шумів, впізнавання знайомих мелодій, сприйняття та відтворення ритмів. Для вивчення асиметрії нюхо- вого гнозису було використано лінійку та такі знайомі запахи, як гірчиці, оцту, валеріани, лаванди, апельсину, хвої, арахісове масло. Для вивчення кінестетичного праксису було використано такі методики: виконання простих інструкцій, дії з реальними предметами, дії 3 уявними предметами, виконання символічних дій, перенос поз по кінетичному зразку, оральний праксис. Для вивчення кінетичного (динамічного) праксису було використано такі методики: проба кулак-ребро-долоня, лайкдолоня, реакція вибору (конфліктна реакція вибору), малювання фігур, графічна проба «Паркан». Для вивчення просторового праксису було використано пробу Хеда, відтворення співвідносного положення кистей обох рук, а для вивчення конструктивного праксису: візуально-моторний тест Л. Бендера, копіювання об’ємних геометричних фігур Л. І. Васермана. Також використали неврологічні проби для дослідження стану мозочка: ходи, утримання рівноваги, координація рухів кінцівок. При нейропсихологічному дослідженні пам'яті було використано такі методики: відтворення подій, запам'ятовування зорових образів, проба трійка, проба на асоціативну пам'ять, смислову пам'ять, запам'ятовування слів без сенсу, запам'ятовування розповідей. При нейропсихологічному дослідженні уваги було використано такі методики: коректурні проби Б. Бурдона, тест «Колір-слово» Дж. Р. Струп, лабіринти, переплутані лінії, проба Х. Мюнстерберга. При нейропсихологічному 
дослідженні мовних функцій було використано такі методики/проби: розуміння складних логіко-граматичних конструкцій (флективні відношення, інтровертировані конструкції, подвійне заперечення, просторові відношення, синоніми, антоніми, омоніми, інтонація), читання вголос, читання мовчазне (швидкісне), письмо під диктовку та самостійне, лічба (елементарна, автоматизована, серійна, потрійна). При нейропсихологічному дослідженні інтелектуальних процесів функцій було використано такі методики: третій зайвий, розуміння сюжетних картин, підбір картини по розповіді дослідника, розуміння картин 3 конфліктним сенсом, встановлення протилежностей, класифікація предметних зображень, прогресивні матриці Дж. Равен, методика Л. С. Виготского-Л.С.Сахарова (узагальнення, відволікання, класифікації і формування понять). При нейропсихологічному дослідження формування понять було використано такі методики: визначення понять, порівняння понять, встановлення відношень, підбір понять, вербальні аналогії, виключення зайвого, пошук істотних ознак, асоціативний експеримент, обмежений потік асоціацій. При нейропсихологічному дослідження дискурсивного мислення було використано такі методики: продовження числового ряду, рішення арифметичних задач, заповнення математичного матеріалу, розуміння умов задач, рішення силогічних задач (Т. В. Чернігівська, В. Л. Деглін). Дослідження когнітивних спотворень пов'язаних із нестачею інформації, надміром інформації, відсутності сенсу, особливостей пам’яті здійснювалося під час бесіди із застосуванням журналу «National Geographic». При нейропсихологічному дослідженні емоційної сфери було використано такі методики: реакція на невдачу та вдачу, сприйняття емоційного тону сюжету, сприйняття емоційного тону розповідей, метод вільних асоціацій, методика вивчення співпереживання. Також використали тест на совість (етична дилема 3 двома ситуаціями на залізничній коліі) для вивчення зв'язку між когнітивними процесами та емоційною сферою. Як комплексну методику окремо використовували тест малювання годинника. Тест Розенцвейга. Оскільки нейропсихологічне дослідження є розмірковуючим дослідженням за потреби долучалися інші проби та тести $[2 ; 3 ; 5 ; 6 ; 8 ; 10 ; 17]$.

Для усунення елементу суб'єктивності при інтерпретації результатів нейропсихологічного дослідження було використано прилади біометричного дослідження: мобільний нейроінтерфейс EMOTIV Ерос+ та амбулаторний інфрачервоний окулограф GP3 HD Eye Tracker 150Hz GAZEPOINT. А також відповідне програмне забезпечення: EmotivPRO, EMOTIV Brain Activity Map, Gazepoint Analisys Tryal v.4.1.0. [13; 14]. Це дозволяє знати куди дивиться досліджуваний і які в нього в цей момент когнітивні та емоційні показники, а також знати у яких ділянках мозку яка активність. 
Поширеність первинного симптомокомплексу серед досліджуваної вибірки

\begin{tabular}{|l|c|c|}
\hline Синдроми порушення функціонування передньої частини мозку & Чоловіки & Жінки \\
\hline Орбіто-фронтальної частини префронтальної кори мозку & & \\
\hline Дорсолатеральної частини префронтальної кори мозку & $53 \%$ & $41 \%$ \\
\hline Передньої цингулярної кори мозку & $28 \%$ & $37 \%$ \\
\hline Вентромедіальної частини префронтальної кори мозку & $10 \%$ & $10 \%$ \\
\hline
\end{tabular}

На сучасному етапі у нейропсихології діагностика когнітивних порушень шляхом виключення альтернатив (диференційний діагноз) не втратила актуальності при кваліфікації симптомів. Використавши цей підхід, було сформовано три компоненти симптомокомплексу психічної стадії девіацій.

На основі кластерного аналізу було виявлено чотири групи осіб з ядерними симптомами, що відповідають за мінімальні порушення функціонування передньої частини мозку. Власне це і є первинний симптомокомплекс (див Табл. 1).

Для першої групи з проявами дисфункції орбіто-фронтальної частини префронтальної кори мозку характерним були: інфантильність; імпульсивність; емоційна лабільність; гедоністична мотивація; моральна агнозія; моральна апраксія; пошукова активність; схильність до ризику.

У даному випадку інфантильність виглядає, як затримка (недорозвиток) чи регресія до найбільш ранніх етапів розвитку. Проявляється інфантильність імпульсивними реа- кціями притаманними для дітей. Дуже нагадує захисний механізм при тривозі, фруструючих впливах, внутрішньо особистісному конфлікті. Також характерним $€$ непосидючість (гіперактивність), слабість вольових установок та безтурботність, балакучість, наївні фантазії.

Імпульсивність проявляється підвищеною розгальмованістю, гіперактивністю, вибуховістю, активною прямою агресією (конфліктність, грубість). 3 часом агресія набуває адиктивного і патологічного характеру.

У цієї категорії осіб емоційній лабільності є специфічною: швидка і часта маломотивована зміна емоцій від нейтральних до ейфорійних. Ця емоційна жвавість, якщо так можна висловитися, часто цих осіб робить лідерами у групі. Характерною також $є$ лабільність уваги.

Гедоністична мотивація проявляється непереборним бажанням негайно досягнути задуманого. Такі нетерпеливі особи залежність не лише від об’єкту, а й від часу. Постійно присутнє бажання, щоб події здійснювали- 
ся якомога швидше і часто. Нетерпеливість, відсутність витримки, невміння чекати у ситуаціях 3 відсутністю структуризації часу (наприклад вихідний день) стає причиною частих конфліктів.

Моральна агнозія виникає через некритичність мислення, відсутність критичної самооцінки і свого стану, неврахування бажань інших, а також невміння зіставляти свої вчинки 3 реальною обстановкою призводить до недостатності моральних переживань, безпечності, легкодумства та тенденції до непродуманих і своєрідних аморальних дій. Часто перед собою ставлять такі цілі, які явно для них складні. Нездатність до складних і тривалих відношень, спричиняє постійний пошук нових секс-партнерів, можна сказати навіть «полювання за ними». Також характерна жвава уява/фантазія, а точніше неконтрольована уява, яка позбавлена цензури робить цих людей цікавими, які легко переступають через табу, правила і норми.

Моральна апраксія проявляється нездатністю дотримуватися правил/закону при його знанні, і проявляється безвідповідальністю, делінквентністю, вульгарністю, лайливістю та сексуальною розпущеністю.

Пошукова активність (цікавість), яка полягає у постійному прагненні до новизни, а також сенсорний голод (смак небезпеки) 3 гедоністичною мотивацією спонукають до пошуку все нових і складніших способів досягнення задоволення екстремальними заняття- ми, експериментуванням 3 новими психоактивними речовинами, у сексуальних девіаціях також присутне прагнення до різноманіття, експериментування та домінантності.

Для другої групи з проявами дисфункції дорсолатеральної частини префронтальної кори мозку характерним були: слабовольність, конформізм, сугестивність, наслідуваність, простодушність, наївність, знижена увага.

Слабовольність проявлялася нездатністю до активної і цілеспрямованої діяльності без зовнішнього впливу, безпорадністю, несамостійністю у прийнятті повсякденних рішення, а також легкістю включення у будь-яку діяльність без зважування всіх за і проти. Характерною є дезорієнтацією у бутті, знижена спонукаюча мотивація, беззахисність. Працюють не на себе, а на когось, допомагають втілювати у життя чужі мрії, а не свої, не створюють свою модель світу, а використовують створену міфодизайнерами. Майже нездатні до інтроспекції.

Надзвичайно виражений конформізм стосовно оточуючих/суспільства. Присутній страх потенційної розлуки, чи страх бути покинутим людиною з якою є тісний зв'язок. Через це виникає нав'язливість, пасивна покірність, податливість і відмова від будь-яких вимог до оточуючих. Крім того, покора спрямована ще на зняття із себе відповідальності за поведінку і за рішення у життєво важливих питаннях, плануванні майбутнього. Але варто наголосити, на домінуванні егоцентричної, а 
не альтруїстичної мотивації. Тому, часто цей конформізм, задля збереження приналежності до групи, трансформується у брехливість і догоджання. У сексуальних вподобаннях домінує мазохізм і покора. Через знижену критичність і піддатливість груповому впливу дуже уразливі до автоагресії та інструментальної агресії до інших без особистих мотивів.

Під сугестивністю, як рисою особистості, розуміємо підвищену сенситивність до психологічного впливу зовні 3 відсутністю критичного осмислення та відсутністю прагнення протистояти цьому впливу. Не мислять самостійно, а ретранслюють/відтворюють думки інших під виглядом власних. Все сприймають на віру, глибоко не аналізують. Через легковірність серед них багато фанатиків, але фанатизм носить конформний характер, а не аксіологічний.

Під наслідуваністю розуміємо легкість засвоєння чужих переконань, бажань, прагнень, оцінок, а також імітація манери і стилю поведінки/мови. Вироблені стереотипи не відповідають власним переконанням. Схильні до колекціонування різних предметів, нагромадження, клептоманії та переїдання.

Простодушність - неточне розуміння смислу розуміння вчинків інших та надмірна довірливість через поверхневе мислення. Характерним є сором'язливість, боязкість, інтерналізація провини.

Наївність спричинена недосвідченістю, необізнаністю та образою через розходження очікувань $з$ дійсністю.

Через знижену увага у діяльності домінує монозадачність і сукцесивність.

Експерименти С. Аша та С. Мілгрема, а також теорія соціального поштовху Б. Латане в дечому пояснюють нормативний тиск соціуму і авторитетів у пропагуванні адикцій, що призводить до публічної поступливості індивіда, навіть без особистого прийняття. Проте при одних і тих самих параметрах групи, одні індивіди підпорядковуються групою, навіть, якщо не поділяють іiї переконань, а інші не поступаються своїми переконаннями. Саме особи, з дисфункцією дорзолатеральної частини префронтальної кори, дуже легко піддаються впливу і стають першими серед девіантів. Саме цій категорії осіб притаманна дисоціація девіацій в залежності від зовнішнього впливу.

Особи 3 даним розладом, наче «пластилін», легко піддаються корекції, але ефект нетривалий при поверненні у девіантне середовище.

Для третьої групи, з проявами дисфункції передньої цингулярної кори мозку, характерним були: антиципаційна некомпетентність, ригідність, застрягання на певному виді діяльності/емоції чи особистості/ квазіособистості, прогностична нездатність, інтелектуальна слабкість, консерватизм.

Антиципаційна некомпетентність - нездатність у повній мірі адекватно планувати i прогнозувати майбутнє. Проте типових ситуа- 
ціях це не проявляється. Знаючи про свою інтелектуальну неспроможність, у нових ситуаціях виникає некритичність та схильність до вчинків без розуміння наслідків своїх дій. Це пов'язано не 3 втратою навичок чи здатністю набувати нові, а через нездатність зіставити власний чи чужий досвід 3 поточною ситуацією і передбачити поведінку власну та оточуючих у майбутньому.

Ригідність (інертність) це негнучкість/ тугорухомість всієї психічної діяльності. Нездатність людини змінити свою поведінку (думку, відношення, установку, мотиви, модус переживання тощо) у відповідності до змін ситуації, а притримуватися одного способу дій у всіх ситуаціях - контекст незалежний стиль прийняття рішення у невизначених ситуаціях 3 вільним вибором. Це стосується i фіксації на певних об'єктах, збереженні емоційного їх значення, а це породжує ревнивість. Характерна впертість, відсутність компромісів, тривога, боязкість і неприємні очікування, підозріле, презирливе, вороже ставлення до інших, нав'язливі сумніви призводять до відчуження та соціальної ізоляції. Проте, у частини досліджуваних (чоловіки 62\%, жінки $37 \%$ ) через присутність ілюзії вищості над іншими у груповій діяльності присутнє прагнення до лідерства. Через знижену емоційність, відсутність емпатії, байдужість, моторну розгальмованість, дратівливість, підвищену агресивність $є$ схильними до протиправних дій.

У психічно здорових людей присутнє вірогіднісне прогнозування із багатьма варіантами розвитку подій. Тоді, як у цієї групи девіантів присутне моноваріантний прогноз, який вибудовується суто на одному суб'єктивно значимому прогнозі розвитку подій. Навіть, якщо запропонувати інші варіанти розвитку подій, то все одно тяжіють виключно до свого єдиного. Це інертне повторення одних і тих самих дій, при зміні обставин контексту легко виявляється при тестах із серійними арифметичними операціями. $Є$ дві крайності у прогнозі: «все буде добре» і повторюють як мантру, або «все буде погано» і поєднується 3 почуттям неповноцінності. Відсутня картина майбутнього та домінує орієнтація на теперішній час. Також характерним $є$ максималізм, що проявляється у крайнощах стосовно поглядів, емоцій, бажань - або все, або нічого. У нейтральних умовах ці інтелектуальні персеверації не помітні для оточуючих і розцінюється як розгубленість чи дивакуватість. При виконанні тестів на інтелект, коли обмеженістю часом штучно створюється керований стрес (стан напруженості) - розлад проявляється дуже яскраво. Першим з'являється звуження, трудності розподілу і переключання уваги. У стресових ситуаціях є абсолютно дезадаптованими, нездатні не те, що надати допомогу іншому чи покликати на допомогу, а нездатні до самовладання, з'являються помилки сприйняття, порушення пам'яті, порушується хронометрія, порушується складні рухи тощо. Звична поведінка витісняється стерео- 
типністю, яка може бути проявлена у крайній збудженості, або у загальмованості.

Поверхневе судження та безваріантність моделі буття стають міцним грунтом для ортодоксального фанатизму зі стійкими життєвими переконаннями і принципами. Полюбляють, можна сказати, навіть одержимі дотримуванням церемоніалів, ритуалів і шаблонів у поведінці, стилі одягу, мові та правил. Страшно не люблять новизни. Характерним є сексуальний фетишизм. При здійсненні девіантної дії виникає емоційна розрядка. У цій групі найбільше затятих геймерів, гравців азартних ігор (лудоманія), осіб з переїданням на вживанням алкоголю.

Структура девіантності, образно кажучи, є «залізо-бетонною», і дуже важко піддається корекції.

Існує зв'язок між проявом синдрому i рівнем соціальної адаптації. При мінімальних проявах є добре адаптовані у суспільстві. При максимальних проявах через динамізм соціальних процесів явно дезадаптовані і невротичні. Тому особи з цією дисфункцією мозку шукають прихисток у консервативних і сталих середовищах (релігійні організації, державні установи, товариства тощо).

Для четвертої групи з проявами дисфункції вентромедіальної частини префронтальної кори мозку характерним були: харизматичність, відсутність совісті, відсутність емпатії, хороші інтелектуальні здібності.

Харизму розглядаємо, як інтеграцію егоцентризму, завищеної самооцінки та прагнення до публічності. Егоцентризм проявляється фіксацією уваги на собі, своїх інтересах, бажаннях, почуттях. Надмірна егоцентричність, яка в деяких ситуаціях не помітна. За вдаваними чарівністю і дружелюбністю насправді приховується холодність, жорстокість i меркантильність. Почуття переваги, вибраності, неординарності змінюе структуру «Яконцепції» та самооцінку. Жага визнання, надмірна потреба у захопленні оточуючих, яскраве самоствердження, марнославство, прагнення вирізнятися реалізується ранговими іграми у суспільстві (владні структури), гномічною діяльністю, або у шоу-бізнесі. Адже яскравість уяви, вражень та фантазій дозволяють легко перевтілюватися в інші образи, ігнорувати реальність і занурюватися у світ мрій.

Совість, ми розглядаємо, як комплекс здатностей до поступливості, до почуття провини та стійкості до спокус. Натомість, присутні завищена самооцінка, лицемірство, безвідповідальність, екстерналізація провини, самовпевненість, егоїзм, насильство (надають перевагу відтермінованій агресії та непрямій), дії носять імпульсивний характер, схильність маніпулювати та залякувати. Відсутність сорому почуття, обов'язку та відповідальності роблять таких осіб небезпечними для суспільства.

Розвинений інтелект дозволяє експлуатувати, маніпулювати і паразитувати на інших. У цьому стані величі сексуальними впо- 
добаннями є садизм та свінгерство. Часто використовують псевдосуїцид для появи почуття провини у оточуючих та контролю над ними. Характерна саме неімпульсивна (відтермінована), інструментальна (проактивна) та опосередкована агресія.

При лонгітюдному спостереженні було виявлено цікавий психічний феномен - егоїстичний сором, який виникає через дискомфорт між надуманим Я і реальним, адже у таких осіб інтелект середній і високий. Дуже часто ця критична самооцінка стає причиною справжньої суїцидальної поведінки, самоприниження та схильності до сексуального мазохізму. У цей період надають перевагу психоактивним речовинам з пригнічуючим ефектом. У період виходу із цього стану перевагу надають психостимуляторам та галюциногенам. При тесті на діагностику совісті (етична дилема 3 двома ситуаціями на залізничній колії). Психічно здорові люди з усвідомленням і почуттям моральної відповідальності за свою поведінку, свої вчинки перед самим собою i суспільством у 60-80\% переключить стрілку, i $20 \%$ - зіштовхнуть вгодовану людину з почуттям провини, у цій надуманій діагностичній ситуації. Індивіди без совісті, у всіх випадках переключать стрілку і зіштовхнуть людину. Саме важливе, що вони не бачать ніякої різниці між двома ситуаціями і у них не виникає ніяких емоцій при вирішенні цього тесту. У житті керуються лише меркантильними, а не моральними принципами. Саме ці люди у сус- пільстві найчастіше $є$ промоутерами адикцій та девіацій і дуже часто знаходяться на керівних посадах.

Отже, виокремлено чотири найтиповіші профілі (синдромологічні ядра) девіантів пов'язані з дисфункціями:

а) орбіто-фронтальної частини префронтальної кори мозку (дОФПФк);

б) дорсолатеральної частини префронтальної кори мозку (дДЛПФк);

в) передньої цингулярної кори мозку (дПЦк);

г) вентромедіальної частини префронтальної кори мозку (дВМПФк).

3 власного життєвого досвіду, не важко здогадатися у якій галузі/сфері діяльності і на яких ієрархічних стратах суспільства, посадах, професіях можна найчастіше зустріти осіб 3 тими чи іншими нейропсихологічними особливостями.

\section{Вторинний симптомокомплекс пред-} ставлений перебуванням під впливом наївного реалізму, домінуванням евристичного (інтуїтивного) мислення і невміння користуватися експертним мисленням (недостатні знання традиційної логіки) у повсякденному житті; низькою комунікативною компетентністю (недостатні знання символічної логіки); дезадаптацією (нездатність вчасно побачити альтернативні шляхи вирішення проблеми).

Варто наголосити, що вторинний симптомокомплекс це не багаторівневий діагноз (традиція американської психіатрії), а пору- 
шення які виникли внаслідок наявності первинного симптомокомплексу мінімальні порушення функціонування передньої частини мозку.

Власне вторинний симтомокомплекс у певному соціальному контексті обставин стає безпосередньою причиною формування девіацій. Вважалося, що вибір форми адиктивної поведінки має, начебто, стохастичний характер. Насправді він залежить від соціального походження, ціннісно-нормативних стандартів, матеріальних можливостей та інформаційного оточення. Прослідковується певна тенденція у вподобаннях різних девіацій при певних нейропсихологічних особливостях. Девіації прийнятні/традиційні для суспільства/ групи характерні для осіб з дДЛПФк; девіації які $є$ неприйнятними і носять конфліктний характер для суспільства притаманні для осіб дОФПФк; натомість декларація однієї поведінки, а жити по діаметрально протилежній девіантній притаманне саме для осіб з дВМП$\Phi$ ж; найбільш нерозбірливими і «зацикленими» на певних девіаціях $є$ особи 3 дПЦк.

Рівень загальної активності мозку визначає тенденцію девіації. Особи із зниженим рівнем активності мозку шукають психостимулюючу діяльність/субстанцію, особи із підвищеною - заспокійливу.

Мотиваційний компонент девіантної поведінки. Було виявлено безпосередній зв'язок між низькою фрустраційною толеран- тністю і атарактивною мотивацією.

Функціональний стан гіпокампа визначає якою буде мотивація. Атарактивна мотивація притаманна особам із зниженою його функціє, а гедоністична - нормальною та підвищеною функцією. Крім того не можна сказати, що чоловіки загалом більше уразливі до появи девіацій - все дуже індивідуально.

\section{Третинний симптомокомплекс - вла-} сне і $є$ адикція - патологічний гомеостаз (постійне прагнення отримувати насолоду), а адиктивні дії втрачають усвідомлений компонент і стають автоматизованим процесом.

Зручними для діагностики є критерії Griffiths (2000) для визначення адикцій: пріоритетність - улюблена діяльність набуває першочергового значення і переважає у когнітивній, емоційній і поведінковій сферах; зміна настрою - супроводжує емоційним підйомом чи переходом до спокою при переході до улюбленої діяльності; толерантність - кількісне збільшення параметрів (час, інтенсивність, введення новизни) діяльності для досягнення звичного ефекту; симптоми відміни - поява неприємних відчуттів (фізіологічних реакцій) при втраті чи раптовому обмеженні можливостей займатися улюбленою діяльністю; конфлікт - протистояння інтрапсихічні, міжособистісні через домінування улюбленої діяльності над іншими видами діяльності (соціальне життя, особисте життя, робота, тощо); рецидив - повернення до улюбленої діяльності після абстинентного періоду [15]. 


\section{Афективний компонент девіантної}

поведінки. 3 анамнезу стало відомо, що більшість досліджуваних вже мали сформовані девіації у віці 12-17p. Формування девіації відбувалося на емоціях, а не на основі свідомого вибору. Рівень узалежненості не є сталим, він є змінним під впливом поточного емоційного стану, соматичного стану, життєвих обставин та зміні світоглядних моделей. Часто виникають ремісії, одні адикції витісняються іншими. Проте, сталим лишається періодичне прагнення відчувати зміну станів свідомості та прагнення до ситуативного щастя. Можна б було створити математичну модель, якби мозок не був настільки мінливим органом під впливом психологічних та когнітивних подій у довкіллі. Застосувавши ЕЕГ моніторинг, виявлено, що в осіб контрольних груп здебільшого активна ліва півкуля протягом дня і достатній рівень активності мозку, тоді як в осіб 3 девіацією протягом дня домінує права півкуля, а у момент очікування і реалізації девіантних дій активізується ліва.

Висновки. На основі комплексного та системного нейропсихологічного дослідження виявлено казуальну структуру девіантної поведінки, що дозволяє сформувати складові ієрархії універсалії (властивості ЦНС) у нейропсихологічній концепції девіантної поведінки:

1. Локальні дисфункції мозку: орбітофронтальної частини префронтальної кори; дорсолатеральної частини префронтальної кори мозку; передньої цингулярної кори мозку; вентромедіальної частини префронтальної кори мозку; мигдалин. Тут застосовується виключно номіналізм - єдине, що існує - це конкретні синдроми ураження різних ділянок мозку (партикуляції). Проміжних форм не існує, можлива лише множинне ураження, яке породжує комбінацію синдромів.

2. Функціональний стан гіпокампу. При нормальному функціональному стані - гедоністична мотивація, а при ослабленому - атарактивна мотивація. Тут присутні неекземпліфіковані атрибути, тобто, такі атрибути, які одночасно не можуть бути. Проте цей стан може бути, як провідна тенденція в індивідуальнопсихологічних особливостях особистості, а може бути динамічним, коли у першій половині дня домінує атарактивна мотивація, а у другій - гедоністична. Врахування цих двох аргументів дозволяє зрозуміти його функціональні особливості.

3. Гностичні, когнітивні, мнестичні порушення - ворожа атрибуція. Вроджені та набуті когнітивні спотворення можуть виникати внаслідок вище перерахованих мозкових дисфункцій/особливостей або мати соматичне походження (механізм тривоги). Відношення можуть бути одномісні (монадичні) та багатомісні (поліадичні).

4. Емоційна сфера. Підвищена активність центру задоволення, ослаблення центру та шляху пригнічення задоволення. Кінцевим результатом $\epsilon$ патологічний гомеостаз/ адикція. 


\section{Перспективи подальших розвідок у} даному напрямі. Розробка ефективних нейропсихокорекційних програм 3 врахуванням нейропсихологічних особливостей осіб з девіантною поведінкою.

\section{Перелік використаних джерел:}

1. Андрух П. Г. (2011). Результаты применения методики ММРІ в психодиагностическом обследовании лиц с зависимостью от различных видов психоактивных веществ (патоперсонологическая характеристика). Международный медицинский журнал, 17(1), 13-19.

2. Бизюк А. П. (2005). Компендиум методов нейропсихологического исследования. Санкт-Петербург: Речь.

3. Бурлачук Л. Ф. (2006). Психодиагностика. СанктПетербург: Питер.

4. Егоров А. Ю. (2006). Нейропсихология девиантного поведения. Санкт-Питербург: Речь.

5. Лурия A. Р. (2008). Основы нейропсихологии (6 изд.). Москва: Академия.

6. Максименко С. Д. (2006). Генеза здійснення особистості. Київ: КММ.

7. Менделевич В. Д. (2003). Наркозависимость и коморбидные расстройства поведения (психологические и психопатологические аспекты). Москва: МЕДпрессинформ.

8. Николаенко Н. Н. (2013). Современная нейропсихология. Санкт-Петербург: Речь.

9. Ткач Б. М. (2006). Індивідуально-психологічні та нейропсихологічні особливості молоді $з$ адиктивною поведінкою. (Дис. канд. психол. наук). Інститут психології ім. Г. С. Костюка АПН України, Київ.

10. Хомская Е. Д. (2007). Нейропсихологическая диагностика. Москва: Институт общегуманитарных исследований В. Секачев.

11. Bechara A., Dolan, S., Denburg, N., Hindes, A., Anderson, S.W. \& Nathan, P.E. (2001). Decision-making deficits, linked to a dysfunctional ventromedial prefrontal cortex, revealed in alcohol and stimulant abusers. Neuropsychologia, 39(4), 376-389.

12. Cavedini P., Riboldi, G., D'Annucci, A., Belotti, P., Cisima, M. \& Bellodi, L. (2002). Decision-making heterogeneity in obsessive-compulsive disorder: ventromedial prefrontal cortex function predicts different treatment outcomes. Neuropsychologia, 40(2), 205-211.

13. Clerc M., Bougrain, L. \& Lotte, F. (Eds.). (2016). Brain-Computer Interfaces 1: Methods and Perspectives. London: ISTE.

14. Duchowski A. T. (2017). Eye Tracking Methodology: Theory and Practice (3rd ed.). Berlin: Springer.

15. Griffiths M. D. (2000). Internet addiction - time to be taken seriously? Addiction Research, 8(5), 413-419.

16. Jackson S. L. (2015). Research Methods and Statistics: A Critical Thinking Approach (5th ed.). Stamford: Wadsworth Publishing.

17. Kolb B. \& Whishaw, I.Q. (2015). Fundamentals of Human Neuropsychology (7th ed.). New York: Worth Publishers.

18. Potenza M. N. (2001). The neurobiology of pathological gambling. Semin. Clin. Neuropsychiatry, 6(3), 217-226.

19. Regard M., Knoch, D., Gutling, E. \& Landis, T. (2003). Brain damage and addictive behavior: a neuropsychological and electroencephalogram investigation with pathologic gamblers. Cogn Behav Neurol, 16(1), 47-53.

20. Specker S. M., Carlson, G.A., Christenson, G.A. \& Marcotte, M. (1995). Impulse control disorders and attention deficit disorder in pathological gamblers. Ann Clin Psychiatry, 7(4), 175-179.

\section{References (Transliteration):}

1. Andruh P. G. (2011). Rezultatyi primeneniya metodiki MMRI $\mathrm{v}$ psihodiagnosticheskom obsledovanii lits $\mathrm{S}$ zavisimostyu ot razlichnyih vidov psihoaktivnyih veschestv (patopersonologicheskaya harakteristika). Mezhdunarodnyiy meditsinskiy zhurnal, 17(1), 13-19.

2. Bizyuk A. P. (2005). Kompendium metodov 
neyropsihologicheskogo issledovaniya. Sankt-Peterburg: Rech.

3. Burlachuk L. F. (2006). Psihodiagnostika. SanktPeterburg: Piter.

4. Egorov A.Yu. (2006). Neyropsihologiya deviantnogo povedeniya. Sankt-Piterburg: Rech.

5. Luriya A. R. (2008). Osnovyi neyropsihologii (6 izd.). Moskva: Akademiya.

6. Maksimenko S. D. (2006). Geneza zdysnennya osobistosti. Kyiv: KMM.

7. Mendelevich V. D. (2003). Narkozavisimost i komorbidnyie rasstroystva povedeniya (psihologicheskie i psihopatologicheskie aspektyi). Moskva: MEDpressinform.

8. Nikolaenko N. N. (2013). Sovremennaya neyropsihologiya. Sankt-Peterburg: Rech.

9. Tkach B. M. (2006). Individualno-psihologichni ta neyropsihologichni osoblivosti molodi $\mathrm{z}$ adiktivnoyu povedinkoyu. (Dis. kand. psihol. nauk). Institut psihologii Im. G.S.Kostyuka APN Ukraini, Kyiv.

10. Homskaya $\quad$ E. D. (2007). Neyropsihologicheskaya diagnostika. Moskva: Institut obschegumanitarnyih issledovaniy V. Sekachev.

11. Bechara A., Dolan, S., Denburg, N., Hindes, A., Anderson, S.W. \& Nathan, P.E. (2001). Decision-making deficits, linked to a dysfunctional ventromedial prefrontal cortex, revealed in alcohol and stimulant abusers. Neuropsychologia, 39(4), 376-389.

12. Cavedini P., Riboldi, G., D'Annucci, A., Belotti, P., Cisima, M. \& Bellodi, L. (2002). Decision-making heterogeneity in obsessive-compulsive disorder: ventromedial prefrontal cortex function predicts different treatment outcomes. Neuropsychologia, 40(2), 205-211.

13. Clerc M., Bougrain, L. \& Lotte, F. (Eds.). (2016). Brain -Computer Interfaces 1: Methods and Perspectives. London: ISTE.

14. Duchowski A. T. (2017). Eye Tracking Methodology: Theory and Practice (3rd ed.). Berlin: Springer.

15. Griffiths M. D. (2000). Internet addiction - time to be taken seriously? Addiction Research, 8(5), 413-419.
16. Jackson S. L. (2015). Research Methods and Statistics: A Critical Thinking Approach (5th ed.). Stamford: Wadsworth Publishing.

17. Kolb B. \& Whishaw, I.Q. (2015). Fundamentals of Human Neuropsychology (7th ed.). New York: Worth Publishers.

18. Potenza M. N. (2001). The neurobiology of pathological gambling. Semin. Clin. Neuropsychiatry, 6(3), 217-226.

19. Regard M., Knoch, D., Gutling, E. \& Landis, T. (2003). Brain damage and addictive behavior: a neuropsychological and electroencephalogram investigation with pathologic gamblers. Cogn Behav Neurol, 16(1), 47-53.

20. Specker S. M., Carlson, G.A., Christenson, G.A. \& Marcotte, M. (1995). Impulse control disorders and attention deficit disorder in pathological gamblers. Ann Clin Psychiatry, 7(4), 175-179.

\section{Tkach Bohdan}

PhD in Psychology, Doctoral Candidate of I. O. Sinitsy Laboratory of Educational Psychology, Institute of Psychology H. S. Kostyuk of the National Academy of Educational Sciences of Ukraine, Kyiv (Ukraine)

\section{NEUROPSYCHOLOGICAL CHARACTERISTICS OF PEOPLE WITH DEVIANT BEHAVIOUR}

\section{ABSTRACT}

The article presents a casual structure of deviant behaviour, created on the basis of comprehensive and systematic neuropsychological study. It is suggested to conduct a neuropsychological study in conjunction with a biometric one (eye tracking and EEG) in order to reduce subjectivity in the interpretation of diagnostic tests results. Three components of symptom complex of deviances' mental stage have been outlined by eliminating the alternatives. The initial symptom 
complex includes minor malfunctions of the frontal part of the brain: the orbitofrontal prefrontal cortex; the dorsolateral prefrontal cortex; anterior cingulate cortex; ventromedial prefrontal cortex. It has been established that the secondary symptom complex is predetermined by a personality being influenced by naïve realism, dominance of heuristic thinking and inability to apply expert thinking in everyday life; low communication competence; disadaptation resulting from inability to find in time the alternative ways of problem solving. The tertiary complex symptom is addiction itself - pathological homeostasis (constant desire to derive satisfaction), when addictive actions lose a conscious component and become an automated process. It appears that the choice of addictive behaviour pattern is not a stochastic process, but it depends on social background, a system of values and norms, financial situation and information environment. It has been found out that a normal functional state of the hippocampus predetermines hedonic motivation, and a weakened one - ataractic motivation. It has been established that all neuropsychological types of a personality with deviant behaviour are characterized by critical thinking reduction and automated performance of deviant actions. On the basis of continued EEG monitoring it was discovered that the people belonging to control groups are mostly left-brain dominant during the day and their brain activity is high enough, while the deviants are right-brain dominant during the day and when in anticipation and in the process of a deviant activity the left hemisphere is activated. The role of every neuropsychological profile of a personality in encouraging deviant tendencies or prevent them from spreading in the modern society has been defined.

Key words: deviant behaviour, neuropsychological diagnostics, neuropersonology, symptom complex, brain malfunctions.

\section{Ткач Богдан Николаевич}

Кандидат психологических наук, докторант лаборатории психологии обучения имени И. О. Синицы Института психологии имени Г. С. Костюка Национальной академии педагогических наук Украины, г. Киев (Украина)

\section{НЕЙРОПСИХОЛОГИЧЕСКИЕ ОСОБЕННОСТИ ЛИЦ С ДЕВИАНТНЫМ ПОВЕДЕНИЕМ}

Аннотация. В статье представлены казуальная структура девиантного поведения, которая созданная на основании комплексного и системного нейропсихологического исследования. Предложено нейропсихологическое исследование осуществлять вместе с биометрическим (окулография и ЭЭГ) для устранения элемента субъективности при интерпретации результатов диагностики. Сформированы три компонента симптомокомплекса психической стадии девиаций путем исключения альтернатив. Показано, что первичный симптомокомплекс представлен минимальными нарушения функционирования передней части мозга: орбитофронтальной части префронтальной коры мозга; дорсолатеральной части префронтальной коры мозга; передней цингу- 
лярной коры мозга; вентромедиальной части префронтальной коры мозга. Установлено, что вторичный симптомокомплекс обусловлен нахождением личности под влиянием наивного реализма, доминированием эвристического мышления и неумением пользоваться экспертным мышлением в повседневной жизни; низкой коммуникативной компетентностью; дезадаптацией из-за неспособности вовремя увидеть альтернативные пути решения проблемы. Показано, что третичный симптомокомплекс это, собственно, и является аддикция - патологическое гомеостаз (постоянное стремление получать наслаждение), а аддиктивные действия теряют осознанный компонент и становятся автоматизированным процессом. Установлено, что выбор формы аддиктивного поведения не является стохастическим процессом, а зависит от социального происхождения, ценностно-нормативных стандартов, материальных возможностей и информационного окружения. Обнаружено, что при нормальном функциональном состоянии гиппокампа присутствует гедонистическая мотивация, а при ослабленном - атарактивна мотивация.

Ключевые слова: девиантное поведение, нейропсихологическая диагностика, нейроперсонология, симптомокомплекс, мозговые дисфункции, мотивация, аффективная cфepa. 